\title{
THE STUDY OF THE CHEMICAL COMPOSITION, EFFECTS ON BEHAVIOURAL RESPONSES AND THE ANTIHYPOXIC ACTIVITY OF THE HERBAL TEA AND THE DRY EXTRACT ON ITS BASIS
}

\author{
Ya.S.Kolisnyk, T.V.Upyr, O.M.Koshoviy, S.Yu.Shtrygol, A.M.Kovaleva \\ National University of Pharmacy
}

Key words: black horehound; white nettle; wormwood; herbal tea; substance; behavioural responses; antihypoxic activity

\begin{abstract}
The chemical composition and pharmacological activity of the dry extract based on the herbal tea composed of black horehound (Ballota nigra) herb, white nettle (Lamium album) herb, wormwood (Artemisiae absinthii) herb in equal amounts have been studied. As a result of the chemical study of the main groups of biologically active substances in the herbal tea and the extract on its basis the presence of phenolic compounds such as derivatives of hydroxycinnamic acid, hydroxycoumarins, flavonoids and their quantitative content have been determined. In the research objects aglycons of flavonoids (luteolin, kaempferol, quercetin, apigenin) have been idenified. $70 \%$ ethanol provides a more complete extraction of phenolic compounds from the herbal tea: the content of hydroxycinnamic acid and flavonoids is higher than in the infusion of the herbal tea, it is more than $60 \%$ and $80 \%$ respectively; the total amount of phenolic compounds in the dry extract is greater than in the infusion - more than $10 \%$ (calculated with reference to a dry residue). The results of the pharmacological research suggest the presence of the sedative effect of the dry extract from the herbal tea in the dose of $400 \mathrm{mg} / \mathrm{kg}$. The dry extract from the herbal tea exhibits the antihypoxic activity that exceeds the activity of Piracetam, thus proving its cerebroprotective action.
\end{abstract}

In the last decades diseases associated with the human higher nervous dysfunctions remain one of the most important medical and social problems of most countries in the world, first of all, due to high prevalence and severe consequences for public health.

According to the World Health Organization (WHO), approximately $6.7 \mathrm{mln}$. people die from cerebrovascular diseases annually in the world. Insult is the second most common cause of death; 6150000 inhabitants of the Earth (92 per 100000 ) died from insult in 2008 , i.e. $10.8 \%$ of the total mortality. In Ukraine 754461 patients died in 2008: of them from insult - 42422 (91.8 per 100000 of the population, $5.6 \%$ of all the dead) $[9,10,12]$.

For the treatment of cerebrovascular diseases, in which pathogenesis hypoxia is of key importance, medicines of various groups are used: nootropic (piracetam), amino acid and peptidergic, acetylcholinergic (donepezil, galantamine, rivastigmine), glutamatergic; when using them a number of side effects appears. The use of herbal drugs in patients with cerebrovascular disease is one of the alternative therapies accelerating normalization of the functions of the nervous system [11]. Therefore, development of effective herbal medicines in cerebrovascular diseases is an important task.

The aim of the work was to study the chemical composition, identify the effects on behavioural responses and the possible antihypoxic activity of the herbal tea and the dry extract on its basis.

Materials and Methods

The objects of the research were the herbal tea composed of black horehound (Ballota nigra) herb, white nettle (Lamium album) herb, wormwood (Artemisiae absinthii) herb in equal amounts and the dry extract on its basis.

To obtain the herbal tea the mixture of black horehound herb, white nettle herb, wormwood herb in the ratio of 1:1:1 was used. From $10 \mathrm{~g}$ of the herbal tea the infusion was obtained by the standard technology, and it was further studied [1].

To obtain the dry extract, $100 \mathrm{~g}$ of the herbal tea was poured with $1000 \mathrm{ml}$ of $70 \%$ ethanol and infused for a week, filtered, allowed to settle within 24 hours, evaporated under vacuum to a dry extract. The extract yield was $7.8 \%$. To determine the qualitative composition of the infusion and the extract obtained conventional research methods - qualitative reactions, paper chromatography (PC) and thin-layer chromatography (TLC) were used. Hydroxycinnamic acids and flavonoids were studied by the method of two-dimensional PC in comparison with authentic samples of hydroxycitric acids in the systems: (direction I) $n$-butanol - acetic acid - water (4:1:2) and (direction II) 5\% acetic acid with the subsequent processing of chromatograms with ammonia vapour. To identify hydroxycoumarins the infusion and the extract were chromatographed (PC) in the systems of chloroform ( $25 \%$ formamide) and hexane ( $25 \%$ formamide) with the subsequent examination of chromatograms in the filtered UV light before and after processing with $10 \%$ alcoholic solution of potassium hydroxide.

The quantitative determination of derivatives of hydroxycinnamic acid, flavonoids and phenolic compounds was 
Table 1

The quantitative content of the main groups of BAS in the infusion and the extract of the herbal tea

\begin{tabular}{|l|c|c|c|c|}
\hline \multirow{2}{*}{ Object } & \multirow{2}{*}{ Yield, \% } & \multicolumn{3}{|c|}{ Quantitative content, \% } \\
\cline { 3 - 5 } & & hydroxycinnamic acids & flavonoids & $\begin{array}{c}\text { the total amount of } \\
\text { phenolic compounds }\end{array}$ \\
\hline Infusion from the herbal tea* & 8.39 & 9.02 & 0.35 & 14.84 \\
\hline Dry extract from the herbal tea & 7.82 & 14.81 & 0.64 & 16.83 \\
\hline
\end{tabular}

Note: * - the content in a dry residue.

conducted by the spectrophotometric method. The optical density was measured in a cell with the layer thickness of $10 \mathrm{~mm}$ on a Specol 1500 spectrophotometer (Switzerland) at an appropriate wavelength. The content of derivatives of hydroxycinnamic acid was calculated with reference to chlorogenic acid at $327 \mathrm{~nm}$, the content of the total amount of flavonoids was calculated with reference to rutin - at the wavelength of $417 \mathrm{~nm}$ after forming a complex with aluminium chloride, the content of the total amount of polyphenolic compounds was calculated with reference to gallic acid - at $270 \mathrm{~nm}$ [3-8].

For statistical significance the experiments were repeated at least five times.

Pharmacological properties of the dry extract from the herbal tea were studied at the Pharmacology Department of the National University of Pharmacy under the supervision of professor Shtrygol S.Yu. To assess the nature of the psychotropic action the standard screening open field test was used.

The antihypoxic activity as a component of the cerebroprotective action was studied on the model of normobaric hypoxic hypoxia with hypercapnia. The doses of the extract were chosen empirically -200 and $400 \mathrm{mg} / \mathrm{kg}$. The reference drug was piracetam (b. 321113, Galychpharm, JSC) in the conditionally therapeutic dose of $400 \mathrm{mg} / \mathrm{kg}$. The experiments were conducted in white mice with the body weight of 16-18 g. Five experimental groups of animals were formed. The reference drug and the dry extract were introduced intragastrically $30 \mathrm{~min}$ before the test [2]. The results are presented in the form of $\mathrm{M} \pm \mathrm{m}$. Statistical processing was performed using Student t-test.

\section{Results and Discussion}

As a result of the chemical study of the main groups of biologically active substances containing in the herbal tea and the extract on its basis the presence of derivatives of hydroxycinnamic acid, hydroxycoumarins, phenolic compounds and flavonoids have been determined. Aglycons of flavonoids - luteolin, kaempferol, quercetin, apigenin were idenified in the research objects by the method of paper chromatography.

The results of determination of the quantitative content of the main groups of BAS identified in the objects of the research are given in Tab. 1.

$70 \%$ ethanol provides a more complete extraction of phenolic compounds from the herbal tea: the content of hydroxycinnamic acid and flavonoids is higher than in the infusion of the herbal tea, it is $64 \%$ and $82 \%$ respectively; the total amount of phenolic compounds in the dry extract is $13 \%$ greater than in the infusion (calculated with reference to a dry residue).

The results of the pharmacological research of the extract are given in Tab. 2 and Tab. 3 .

The results of the open field test indicate the presence of the expressed sedative effect of the dry extract from the herbal tea under study in the dose of $400 \mathrm{mg} / \mathrm{kg}$.

Table 2

The effect of the dry extract from the herbal tea on the indices of the open field test

\begin{tabular}{|l|c|c|c|c|}
\hline \multicolumn{1}{|c|}{ Indices for $3 \mathrm{~min}$} & Control $(\mathrm{n}=10)$ & $\begin{array}{c}\text { Piracetam, } \\
400 \mathrm{mg} / \mathrm{kg}(\mathrm{n}=10)\end{array}$ & $\begin{array}{c}\text { Dry extract, } \\
200 \mathrm{mg} / \mathrm{kg}(\mathrm{n}=9)\end{array}$ & $\begin{array}{c}\text { Dry extract, } \\
400 \mathrm{mg} / \mathrm{kg}(\mathrm{n}=9)\end{array}$ \\
\hline $\begin{array}{l}\text { Locomotor activity } \\
\text { (the number of squares) }\end{array}$ & $53.7 \pm 7.7$ & $65.0 \pm 9.9(+21.0 \%)$ & $\begin{array}{c}51.3 \pm 4.4 \\
(-4.5 \%)\end{array}$ & $\begin{array}{c}29.3 \pm 10.3 ! \\
(-45.4 \%)\end{array}$ \\
\hline Indicative exploration & & & & \\
activity & & & & \\
1. Rearing & $2.4 \pm 0.9$ & $6.6 \pm 1.8^{*}(+175 \%)$ & $5.9 \pm 1.6(+146 \%)$ & $2.6 \pm 1.6(+13.0 \%)$ \\
2. “Looking” into the holes & $27.3 \pm 5.0$ & $36.9 \pm 4.5(+35.2 \%)$ & $40.9 \pm 4.9(+50.0)$ & $10.0 \pm 4.4^{*}(-63.4 \%)$ \\
3. The sum & $29.7 \pm 5.6$ & $43.5 \pm 3.5^{*}(+46.5 \%)$ & $46.8 \pm 5.2^{*}(+57.6)$ & $12.6 \pm 5.5^{*} !(-57.6 \%)$ \\
\hline Emotional reactions: & & & & \\
1. Boluses & $0.4 \pm 0.17$ & $0.6 \pm 0.2$ & $0.11 \pm 0.02$ & 0 \\
2. Urination & 0 & $0.2 \pm 0.1$ & 0 & $0.1 \pm 0.1$ \\
3. Grooming & $2.4 \pm 0.5$ & $1.5 \pm 0.4$ & $4.33 \pm 1.2$ & $2.2 \pm 1.0$ \\
4. The sum & $2.8 \pm 0.6$ & $2.3 \pm 0.6$ & $4.7 \pm 1.3$ & $2.33 \pm 1.0$ \\
\hline The sum of all activities & $86.2 \pm 10.0$ & $110.8 \pm 9.2(+28.5 \%)$ & $102.8 \pm 10.1(+19.3)$ & $44.2 \pm 16.59^{*}(48.7 \%)$ \\
\hline
\end{tabular}

Note: * - significant changes in the control group $(p<0.05)$; ! - significant changes in the piracetam group $(p<0.05)$. 
Table 3 racetam without a considerable impact on the locomo-

The antihypoxic activity of the dry extract from the herbal tea on the model of normobaric hypoxic hypoxia with hypercapnia in mice

\begin{tabular}{|l|c|c|c|c|}
\hline \multicolumn{1}{|c|}{ Group } & $\begin{array}{c}\text { Dose } \\
\mathrm{mg} / \mathrm{kg}\end{array}$ & $\mathrm{n}$ & $\begin{array}{c}\text { Survival time, } \\
\mathrm{min}\end{array}$ & $\begin{array}{c}\text { \% changes } \\
\text { comparing to } \\
\text { the control }\end{array}$ \\
\hline Control & - & 10 & $43.0 \pm 3.27$ & - \\
\hline Piracetam & 400 & 10 & $61.15 \pm 4.02^{*}$ & +42.2 \\
\hline Dry extract & 400 & 9 & $74.2 \pm 7.63^{*}$ & +72.6 \\
\hline
\end{tabular}

Note: * significant changes in the control group $(p<0.05)$.

It is manifested by inhibition of all types of behavioural activity: locomotor (the number of crossed squares), indicative exploration activity (rearing and "looking" into the holes) and their sum compared to the effects of piracetam, which caused statically significant intensification of manifestations of indicative exploration behaviour, first of all, rearing being a typical manifestation of cognitive functions enhancement for a nootropic drug. The sedative effect of the dry extract studied is confirmed by a clear tendency to the locomotor activity reducing with authentic decrease of the number of the holes explored, the sum of indices of exploration responses and reducing to 0 of the number of fecal boluses. The latter is inhibition of the vegetative support of emotional reactions that is typical for the sedative action.

When using in the dose of $200 \mathrm{mg} / \mathrm{kg}$ the dry extract affected the behaviour of animals in a different way: comparing to the control it increased the indicative exploration activity at the level of the reference drug pi- tor activity.

These results demonstrate the dose-dependent effect of the dry extract under study on the behavioural responses: stimulation of exploration responses is revealed in a lower dose, and with the dose increase the sedative action appears.

As can be seen from Tab. 3, the dry extract in the dose of $400 \mathrm{mg} / \mathrm{kg}$ increases more than one-half the survival time of the mice comparing to the control exceeding piracetam. It indicates a protective effect of the extract primarily on the brain - the organ that is most sensitive to hypoxia.

Therefore, the results of the pharmacological research suggest the presence of the sedative and antihypoxic activity proving the cerebroprotective action of the herbal medicinal product studied.

\section{CONCLUSIONS}

The chemical composition, the influence on the behaviour of animals in the open field test and the antihypoxic activity of the dry extract from the herbal tea composed of black horehound herb, white nettle herb, wormwood herb have been studied.

As a result of the chemical study of the main groups of biologically active substances in the herbal tea with the antioxidant effect and the extracts on its basis the presence of derivatives of hydroxycinnamic acid, hydroxycoumarins, phenolic compounds and flavonoids, as well as their quantitative content have been determined.

The dry extract on the basis of the herbal tea exhibits the sedative and antihypoxic activity confirming its cerebroprotective action.

\section{REFERENCES}

1. Державна фармакопея Украӥни / ДП «Науково-експертний фармакопейний центр». - 1-е вид. - Доп. 2. Х.: ДП «Науково-експертний фармакопейний центр», 2008. - 620 c.

2. Доклінічні дослідження лікарських засобів: метод. рекоменд. / Н.О.Горчакова, І.С. Чекман, І.А.Зупанеиь та ін.; За ред. чл.-кор. АМН України О.В.Стефанова. - К.: Авіценна, 2001. - 528 с.

3. Kolisnyk Ya.S., Kovaleva A.M., Goryacha O.V. // Вісник фармачіï. - 2014. - №2. - C. 59-62.

4. Koshoviy O.M., Kyslichenko V.S., Velma V.V. et al. // Herba Polonica. - 2008. - Vol. 55, №1. - P. 72-77.

5. Kovalyova A.M., Goncharov O.V., Osmachko A.P. et al. // X International Symposium on the Chemistry of Natural Compounds 21-23 November 2013. Tashkent-Bukhara, Uzbekistan. - 2013. - P. 278.

6. Matkowski A., Tasarz P., Szypuła E. // J. of Medicinal Plants Res. - 2008. - Vol. 2(11). - P. 321-330.

7. Ochkur A.V. // Actual Questions of Development of New Drugs: Abstracts of XX International Scientific and Practical Conference of Young Scientists and Students (April 22-23, 2014). - Kh.: Publishing Office, 2014. P. 42.

8. Ochkur O., Kovalyova A., Kashpur N. et al. // The Pharma Innovation J. - 2013. - Vol. 2, №9. - P. 48-50.

9. The top 10 causes of death [Электронный ресурс]. - Режсим достуna: http://www.who.int/mediacentre/ factsheets/fs310/en/index.html

10. The world health report 2002 - Reducing Risks, Promoting Healthy Life [Электронный ресурс]. - Режим docmyna http://www.who.int/whr/2002/en/

11. Vrchovská V., Spilková J., Valentão P. et al. // Food Chemistry. - 2007. - Vol. 105, I. 4. - P. 1396-1403.

12. Населення України (1990-2011рр.). Статистична інформація Держсавної служби статистики України [Электронный ресурс]. - Режим доступа: http://www.ukrstat.gov.ua/operativ/operativ2007/ds/nas_rik/ nas_u/nas_rik_u.html 
ДОСЛІДЖЕННЯ ХІМІЧНОГО СКЛАДУ, ВПЛИВУ НА ПОВЕДІНКОВІ РЕАКЦІЇ ТА АНТИГІПОКСИЧНОЇ АКТИВНОСТІ ФІТОЗБОРУ ТА СУХОГО ЕКСТРАКТУ НА ЙОГО ОСНОВІ Я.С.Колісник, Т.В.Упир, О.М.Кошовий, С.Ю.Штриголь, А.М.Ковальова

Ключові слова: м'яточник чорний; кропива глуха; полин гіркий; фрітозбір; субстанція; поведінкові реакції; антигіпоксична активність Досліджено хімічний склад та фрармакологічну активність сухого екстракту на основі збору, до складу якого входять трава м'яточника чорного, трава кропиви глухої та трава полину гіркого у рівних кількостях. В результаті хімічного вивчення основних груп біологічно активних речовин у зборі та екстракті зі збору встановлено наявність фенольних сполук: похідних гідроксикоричної кислоти, гідроксикумаринів, фрлавоноїдів, та їх кількісний вміст. В об'єктах дослідження були ідентифріковані аглікони фрлавоноїдів (лютеолін, кемпферол, кверцетин, апігенін). 70\% етанол забезпечує більш повну екстракцію феннольних сполук зі збору: вміст гідроксикоричних кислот та фрлавоноїдів більщий, ніж у настої збору понад 60\% та понад 80\% відповідно, вміст суми френольних сполук у сухому екстракті більший, ніж у настої понад $10 \%$ (у перерахунку на сухий залишок). Результати фрармакологічних досліджень свідчать про наявність седативного ефректу сухого екстракту зі збору в дозі 400 мг/ке. Сухий екстракт зі збору виявляє антигіпоксичну активність, перевершуючи пірацетам, що свідчить про церебропротекторну дію.

\section{ИССЛЕДОВАНИЕ ХИМИЧЕСКОГО СОСТАВА, ВЛИЯНИЯ НА ПОВЕДЕНЧЕСКИЕ РЕАКЦИИ И АНТИГИПОКСИЧЕСКОЙ АКТИВНОСТИ ФИТОСБОРА И СУХОГО ЭКСТРАКТА НА ЕГО OCHOBE}

\section{Я.С.Колесник, Т.В.Упыр, О.Н.Кошевой, С.Ю.Штриголь, А.М.Ковалева}

Ключевые слова: белокудренник черный; яснотка белая; полынь горькая; фритосбор; субстанция; поведенческие реакции; антигипоксическая активность

Исследованы химический состав и фрармакологическая активность сухого экстракта на основе сбора, в состав которого входят трава белокудренника чёрного, трава яснотки, трава полыни горькой в равных количествах. В результате химического изучения основных групп биологически активных веществ в сборе и экстракте на его основе установлено наличие фенольных соединений: производных гидроксикоричной кислоты, гидроксикумаринов, фрлавоноидов и их количественное содержание. В объектах исследования были идентифрицированы агликоны фрлавоноидов (лютеолин, кемпферол, кверцетин, апигенин). 70\% этанол обеспечивает более полную экстракцию фенольных соединений из сбора: содержание гидроксикоричных кислот и фрлавоноидов больше, чем в настое сбора свыше $60 \%$ и $80 \%$ соответственно, содержание суммы фенольных соединений в сухом экстракте больше, чем в настое свыше 10\% (в пересчете на сухой остаток). Результаты фрармакологических исследований свидетельствуют о наличии седативного эфрфректа сухого экстракта из сбора в дозе 400 мг/ке. Сухой экстракт из сбора проявляет антигипоксическую активность, по которой он превосходит пирацетам, что свидетельствует о церебропротекторном действии. 